\title{
A cenografia no discursivo literário: enlaçamento enunciativo e ethos no romance Eva Luna
}

\author{
Ernani Cesar de Freitas \\ Marinês Giareta Serena ${ }^{\star \star}$
}

\section{Resumo}

Atualmente, ainda é comum encontrarmos no meio acadêmico certo distanciamento entre as áreas da Linguística e Literatura. No entanto, há estudiosos da língua que já começam a perceber essas duas vertentes como indissociadas uma da outra, uma vez que, de um lado temos a linguística consagrada em estudar textos caracterizados como não literários e de outro, a literatura, responsável por explorar a ordem estética das obras. Diante de um cenário interdisciplinar, o objetivo deste estudo volta-se para descrever e analisar o ethos discursivo da personagem principal do romance Eva Luna, considerando que o discurso literário é configurado por uma cenografia, cuja condição é validar a narrativa ao mesmo tempo em que define o estatuto de enunciador e do coenunciador na situação de enunciação que caracteriza a cenografia instituída no discurso. Os referenciais teóricos aqui abordados inserem-se na perspectiva da análise do discurso de linha francesa, mais especificamente no dispositivo enunciativo-discursivo proposto por Dominique Maingueneau (1997, 2008a, 2009, 2010) e seus estudiosos, entre os quais Possenti (2008), Souza-e-Silva e Rocha (2009), Freitas e
Facin (2011). Os procedimentos teórico-metodológicos de análise estão ancorados nos conceitos de cenografia e ethos discursivo identificados pelas marcas linguístico-discursivas presentes no texto literário, no romance Eva Luna. A pesquisa evidenciou que o ethos discursivo identifica-se a partir de cenas enunciativas construídas, as quais concedem à personagem Eva a qualidade de fiador na narrativa analisada.

Palavras-chave: Romance. Eva Luna. Isabel Allende. Cenografia. Ethos discursivo.

\footnotetext{
Doutor em Letras pela PUCRS, com pós-doutorado em Linguística Aplicada e Estudos da Linguagem (PUC-SP/LAEL); pesquisador nas áreas Linguagem e Trabalho, Semântica Argumentativa, Semiolinguística; professor do Mestrado em Letras da Universidade de Passo Fundo (UPF); professor do Mestrado em Processos e Manifestações Culturais da Universidade Feevale, Novo Hamburgo, RS. E-mail:ecesar@upf.br.

* Graduada em Letras com habilitação em Língua Espanhola e suas respectivas Literaturas; especialista em Ensino e Aprendizagem de Línguas Estrangeiras e Mestra em Letras pela Universidade de Passo Fundo (UPF). E-mail: mgs@upf.br.
}

Data de submissão: fev. 2014 - Data de aceite: abr. 2014

http://dx.doi.org/10.5335/rdes.v10i1.4097 


\section{Introdução}

O tema deste estudo tem como foco a análise do discurso no texto literário, mais especificamente no que diz respeito à construção da cenografia e do ethos discursivo no romance Eva Luna. A delimitação do trabalho está atrelada, portanto, à cenografia e ao ethos da personagem principal da narrativa, Eva Luna. Enfatizamos, neste trabalho, a importância do texto literário para o letramento sob o prisma acadêmico, uma vez que a leitura se constitui como elemento importante ao desenvolvimento do sujeito, não apenas da linguagem, mas na construção sociodiscursiva desse gênero textual, o literário, mediante a narrativa ficcional. A questão norteadora foi assim definida: no romance $E v a$ Luna, de Isabel Allende (1987/1994), é possível descrever e analisar o ethos discursivo, considerando as particularidades da escrita literária no que diz respeito à situação de enunciação, particularmente, as cenografias construídas nos vários enunciados que se verificam no fio discursivo da narrativa.

A partir dessa assertiva, o objetivo geral deste artigo consiste em descrever e analisar o ethos discursivo da personagem principal no romance $E v a$ Luna, através do desenvolvimento da narrativa, a partir da qual é possível depreender a discursivização observada nos capítulos do romance que mostram cenografias construídas e que dessas resultam ethé discursivos. Em conformidade com o objetivo geral, estabelecemos os objetivos específicos: a) abordar os elementos que constituem a semântica global de Maingueneau (1984/2008a); b) identificar a cenografia e o ethos discursivo presentes na obra Eva Luna, em dois de seus capítulos; c) compreender de que forma se constrói o ethos discursivo na voz da personagem Eva Luna, mediante a situação de enunciação em que se desenvolve discursivamente a narrativa; d) mostrar como se constitui a cenografia enunciativa, da qual deriva o ethos discursivo da personagem Eva.

A fundamentação teórica que sustenta a análise do romance concentra-se na teoria enunciativo-discursiva de Dominique Maingueneau (1997, 2008a, 2009, 2010) e seus estudiosos, entre os quais citamos Possenti (2008), Souza-e-Silva e Rocha (2009), Freitas e Facin (2011), e da escrita literária, também conforme Maingueneau (2009).

$\mathrm{O}$ corpus de pesquisa tem como base 0 romance Eva Luna, da escritora chilena Isabel Allende. A obra, uma publicação da Bertrand Brasil, foi publicada em 19871, apresenta-se em 328 páginas, divididas em 11 capítulos e mais o capítulo final. O recorte desse corpus está previsto em analisar como se dá a construção da cenografia e do ethos discursivo nos capítulos três e onze, por entendermos que são os que apresentam cenografias e ethos nos quais a personagem principal, Eva, mostra-se mais presente no discurso. Realizamos este estudo por meio da pesquisa descritiva, bibliográfica, com abordagem qualitativa. 
Além da introdução, considerações finais e referências, este artigo conta, em sua estrutura, com sete seções: inicialmente, apresentamos interface teórica entre enunciação e literatura e, para tanto, apoiamo-nos em Barthes (2004), Bakhtin (1992), Fiorin (2011) e Maingueneau (2009); posteriormente, nossas reflexões voltam-se para a importância da leitura como processo de comunicação e interação verbal e social na vida do ser humano. Considerando a relevância do ato de ler na vida do sujeito, descrevemos alguns aspectos relacionados à leitura e à literatura. Para tanto, contamos com as contribuições de Koch (1984), Bordini e Aguiar (1988), Kleimann (1999) e Zilberman (1999). Ao mencionarmos os planos constitutivos da semântica global conforme postulados de Maingueneau (2008a), justificamos o porquê dessas categorias e a relevância destas para a concretização dos objetivos em questão. $\mathrm{Na}$ sequência, nossa atenção volta-se para a cenografia em consonância com o texto literário e ao ethos discursivo. Em seguida, procedemos à análise do corpus, a fim de aplicar a metodologia e os conceitos teóricos, de base, no romance $E v a$ Luna, apontando de que forma se dá esse processo. Na seção seguinte, metodologia e análise, destacamos as categorias que norteiam a pesquisa. Apresentamos, também, a fim de situar o leitor, uma sinopse da obra e, na sequência, é explicitada a análise de dois capítulos do romance objeto do estudo proposto. Salientamos que a opção em trabalhar apenas esses dois dos capítulos do romance deve-se às limitações naturais de um artigo. Nas considerações finais, comentamos a respeito dos possíveis estudos que a interface possibilita, entre a escrita literária e a teoria enunciativo-discursiva, conforme elementos teóricos fundamentados em Maingueneau.

\section{Enunciação e literatura}

A literatura é uma expressão artística cujo diferencial das demais manifestações se dá pela forma como se apresenta, isto é, pela narrativa que faz uso da palavra, da linguagem. Isso ocorre porque é justamente a linguagem que distingue o texto literário dos demais gêneros no âmbito literário; o escritor dispõe de uma infinita gama de palavras que o permite manipulá-las e organizá-las de forma que produzam um efeito que vá além da sua significação objetiva, possibilitando ao leitor fazer várias interpretações e recriações a partir do texto.

Barthes, em o Rumor da lingua, distingue linguagem científica e linguagem literária. Conforme esse autor,

[...] a linguagem é o ser da literatura, seu próprio mundo: toda a literatura está contida no ato de escrever, e não mais no de "pensar", de "pintar", de "contar", de "sentir" [...] a literatura se vê hoje sozinha a carregar a responsabilidade inteira da linguagem [...] (BARTHES, 2004, p. 5).

Ao pensarmos em literatura sob essa perspectiva, podemos dizer que a literatura se engrandece pela linguagem, ao mesmo tempo em que é pela linguagem 
que a cultura do mundo se consolida literariamente. Portanto, pensar o texto literário como forma de traduzir cultura nos remete ao ato de comunicação, pois "o papel central da linguagem é o de comunicação" (BAKHTIN, 1992, p. 289). Desse modo, Maingueneau (2006, p. 36) comenta que a obra literária não se constitui em um universo fechado, isto é, a obra literária "é a multiplicidade de quadros cognitivos e práticas que lhe conferem sentido".

A relação dialógica cunhada por Bakhtin (1992) permite inferir que a literatura não se caracteriza de forma isolada, mas, ao contrário, ela se revela de forma pluridiscursiva, plurilinguística e pluriestilística. Com base nessas premissas, nosso propósito é aproximar a enunciação e o discurso literário.

Fiorin (2011), na disciplina de seminários especiais, ministrada no Programa de Pós-Graduação em Letras, em 15 de dezembro de 2011, na Universidade de Passo Fundo, comentou que, no meio acadêmico das ciências humanas, é inconcebível, é inadmissível que hoje linguística e literatura andem "de costas" uma para a outra, uma vez que, de um lado, temos a linguística consagrada em estudar textos caracterizados como não literários e, de outro, a literatura responsável em explorar a ordem estética das obras. No entendimento de Fiorin (2011), portanto, não há como separar essas duas vertentes: a dos estudos linguísticos e a dos estudos literários, visto que a literatura se constitui no discurso e é no discurso que a escrita literária se consagra literatura.

A obra literária, de certa forma, representa situações de mundo e de contextos por meio de seu discurso. Desse modo, essas condições de enunciação implicam uma cena de enunciação, a qual não se reduz nem ao texto, nem ao exterior, mas, ao contrário, é pela cena que o discurso é validado e, com ele, a representação cultural exterior, ou seja, a cena do discurso "se legitima através de um circuito: mediante o mundo que instaura, ela precisa justificar tacitamente a cena de enunciação que impõe desde o começo" (MAINGUENEAU, 2009, p. 55).

Assim, expomos de maneira sucinta que é possível uma aproximação entre enunciação e literatura, uma vez que a enunciação vincula-se à noção discursiva e, portanto, aí se estabelecem e se entrelaçam a linguística e a literatura. Traçamos, de forma sintética, algumas considerações referentes à enunciação e à literatura, sobretudo tentamos perceber que essa interface é uma aproximação possível, especialmente se considerarmos que por meio da literatura pode-se representar cultura, modos de viver, tempo, contexto, etc. Na sequência, dedicamos uma seção aos planos que constituem o discurso no âmbito da semântica global, a qual será útil para a análise do corpus. 


\section{Leitura como processo enunciativo}

Estudos relacionados à enunciação podem proporcionar uma comunicação mais eficaz quando partem de uma leitura mais atenta dos enunciados. Atualmente, são comuns os estudos linguísticos voltados à enunciação, pois despertam interesse significativo em quem trabalha com a leitura e com a produção textual. A enunciação, ato produtor do enunciado, é constituída por meio de diversas formações discursivas e ideológicas no discurso, como as condições de produção, quais sejam: tempo, lugar, relações sociais, as intenções, os sujeitos que, juntos, revelam a enunciação como uma interação dinâmica.

$\mathrm{O}$ ato de ler ou apreender informações por meio da leitura ou não, bem como desenvolver habilidades que possam auxiliar na comunicação, está fortemente relacionado à competência leitora e discursiva que somente será possível por meio de uma prática constante de leitura, aliada ao conhecimento linguístico apresentado pelo texto, visto que o sentido não existe em si, mas é determinado pelas posições ideológicas colocadas em jogo no processo sócio-histórico em que os textos são produzidos.

Nesse sentido, buscando a construção do conhecimento, entendemos o romance como um gênero essencial à prática de leitura, uma vez que esse gênero tem um grande poder de abstração e subjetividade, ampliando, considera- velmente, o conhecimento de mundo do leitor. Vejamos, pois, a postura dos Parâmetros Curriculares Nacionais $(\mathrm{PCNs})$ em relação à especificidade do texto literário:

[...] o texto literário constitui uma forma peculiar de representação e estilo em que predominam a força criativa da imaginação e a intenção estética. Não é mera fantasia que nada tem a ver com o que se entende por realidade, nem é puro exercício lúdico sobre as formas e sentidos da linguagem e da língua (PCNs, 1998, p. 26).

Nesse sentido, parece-nos viável pensar na construção de uma prática pedagógica mais qualificada, capaz de possibilitar ao aluno uma reflexão relacionada à língua e à construção de sentidos por meio da linguagem, percebendo o texto como principal material ensino/aprendizagem, pois é por meio dele que se torna possível a análise da língua em uso e o desenvolvimento da competência discursiva dos alunos. Os PCNs organizam-se de modo a conduzir e nortear o trabalho escolar em todo o país, a fim de mudar as práticas pedagógicas cristalizadas ao longo do tempo e que apenas enfatizam o sistema da língua com base em palavras ou frases soltas e atividades isoladas. $\mathrm{O}$ Plano Curricular Nacional defende, portanto, a expansão das possibilidades de uso da linguagem, partindo do texto como unidade de ensino e do desenvolvimento das quatro habilidades linguísticas: ler, escrever, falar e ouvir.

Dessa maneira, entendemos a leitura como elemento importante ao desenvolvimento da linguagem e da competência 
discursiva, bem como à construção da consciência da cidadania em sociedade. No entanto, a leitura não pode ser entendida apenas como um decifrar de códigos, mas como um processo que envolve a interação entre sujeitos, propiciando a construção de/do sentido pelo leitor, isto é, a verdadeira compreensão. Desse modo, a leitura é vista como um processo que envolve, além dos conhecimentos linguísticos e textuais, o conhecimento de mundo do leitor. Koch (1984) destaca que cabe à escola o papel de auxiliar os alunos a tornarem-se leitores competentes, mas não sem pautar sua prática em uma concepção de leitura decorrente da concepção de sujeito, língua, texto e sentido que se adota.

Bordini e Aguiar (1988, p. 11) conferem "à escola a função de formar o leitor". Ainda segundo as autoras,

[...] todos os livros favorecem a descoberta de sentidos, mas são os literários que o fazem de modo mais abrangente. Enquanto os textos informativos atêm-se aos fatos particulares, a literatura dá conta da totalidade do real, pois, representando o particular, logra atingir uma significação mais ampla (BORDINI; AGUIAR, 1988, p. 11).

Desse modo, é na/pela obra literária que o leitor tem a livre movimentação de construir um mundo possível. No entanto, é um mundo que envolve lacunas que, automaticamente, são preenchidas pelo leitor conforme sua experiência de mundo. Zilberman postula que pela leitura o leitor
[...] é mobilizado a emitir um juízo, fruto de sua vivência do mundo ficcional e do conhecimento transmitido. Ignorar a experiência aí depositada equivale a negar a literatura enquanto fato social, neutralizando tudo que ela tem condições de proporcionar (1999, p. 110).

De acordo com Maingueneau (1996), a leitura como processo enunciativo desempenha papel decisivo pelo destinatário na interpretação dos enunciados. No caso do discurso literário, a verdadeira leitura está em associar e construir sentidos na interação com o contexto histórico-social, observando as intenções, opiniões e ideias dos autores.

De modo geral, comenta Maingueneau:

[...] qualquer comunicação escrita é frágil, pois o receptor não partilha a situação de enunciação do locutor. Atinge-se um paroxismo com os textos literários, que alcançam públicos indeterminados no tempo e no espaço (1996, p. 31).

Contudo, esse autor lembra que, ao elaborar um texto, os autores devem ter em mente certo tipo de público, mas que é essência da obra literária circular em tempos e em lugares muito afastados dos da sua produção.

A obra literária vale-se desse enfoque enunciativo, visto que pode ser percebida como interação entre autor e leitor, num tempo e num espaço determinados, realizando uma prática social e cultural, construindo o sentido durante a leitura na interação verbal. Kleiman enfatiza que

[...] a leitura é um ato social, entre dois sujeitos - leitor e autor - que interagem entre si, obedecendo a objetivos e necessidades socialmente determinados (1999, p. 10). 
Maingueneau (2002, p. 20) afirma que

[...] todo ato de enunciação é fundamentalmente assimétrico: a pessoa que interpreta o enunciado reconstrói seu sentido a partir de indicações presentes no enunciado produzido, mas nada garante que o que ela reconstrói coincida com as representações do enunciador.

Tal observação nos remete a pensar que o enunciatário-leitor tem certa liberdade para perceber, ou não, as marcas linguísticas deixadas pelo enunciador, o que pode modificar o entendimento do enunciado.

A leitura pode e deve ser vista como uma atividade complexa, visto que, ao tentar decifrar um texto, o leitor depara-se com uma gama diversificada de competências a percorrer. No entanto, o percurso que o leitor faz, em geral, está mais relacionado aos conhecimentos não linguísticos. Nesse sentido, Kleiman (1999, p. 13, grifo do autor) destaca que "a compreensão de um texto é um processo que se caracteriza pela utilização de conhecimento prévio: o leitor utiliza na leitura o que ele já sabe, o conhecimento adquirido ao longo de sua vida”. No entendimento dessa autora, é mediante a interação de diversos níveis de conhecimento, como o linguístico, o textual e o de mundo, que o leitor consegue construir o sentido do texto. É justamente a utilização desses diversos níveis de conhecimento que interagem entre si, fazendo com que a leitura seja considerada um processo interativo. Kleiman (1999, p. 13) lembra "que sem o engajamento do conhecimento prévio do leitor não haverá compreensão". Assim, temos o texto literário, especialmente 0 romance, o qual durante muito tempo despertou interesse no leitor por suas histórias românticas e com finais felizes. Todavia, o romance moderno apresenta características de informação e de comunicação, trincando com paradigmas cristalizados ao longo do tempo.

Apesar de vivermos a era do computador, da acessibilidade fácil a informações, da era do hipertexto, da possibilidade de mudar o final de uma história, não nos esqueçamos de que

[...] estes jogos não substituem a verdadeira função educativa da literatura, função educativa que não se reduz à transmissão de idéias morais, boas ou más que sejam, ou à transformação do sentido do belo (ECO, 2003, p. 19).

Maingueneau (1996, p. 43) observa que

[...] para um leitor que só dispõe de um saber linguístico, muitas obras seriam parcial ou totalmente ininteligíveis. Não se deve, contudo, esquecer que a leitura das obras contribui também para enriquecer os saberes do leitor, obrigando-o a tecer hipóteses interpretativas que excedem a literalidade dos enunciados. Para abordar um texto, o leitor se apoia, em primeiro lugar, num conhecimento, por menor que seja, do contexto enunciativo. Dispõe de um certo saber de extensão muito variável sobre a época, o autor, as circunstâncias imediatas e distantes e 0 gênero do discurso ao qual a obra pertence.

Nesse sentido, temos o romance, que atrai o leitor contemporâneo, levando em conta que, nas últimas décadas, esse gênero vem ganhando destaque por abordar assuntos atuais e temas polêmicos, além de considerar o contexto de 
produção e os sujeitos, juntamente com questões históricas e culturais. Diante dessa nova realidade, a leitura não pode ser vista como um elemento indissociável entre leitor e produtor, mas, ao contrário, pode exercer no indivíduo um efeito de liberdade e de transformação.

Assim, buscamos ressaltar a importância do texto literário, em especial o romance, como um discurso que apresenta multiplicidades de seus planos e não como algo estanque e detentor de uma única interpretação. Por isso, a próxima seção é dedicada aos planos que constituem o discurso no âmbito da semântica global, que será útil na/para a análise do corpus de pesquisa neste estudo.

\section{Planos constitutivos do discurso da semântica global - uma abordagem enunciativa}

Maingueneau (2008a), em sua obra Gênese dos discursos, explica as diversas formas de coerções a que um discurso é submetido, não discutindo a natureza do sentido e de sua relação com a língua. $\mathrm{O}$ autor propõe outra maneira de fazer análise do discurso, ou seja, uma análise menos linguística e menos gramatical. Assim, na teoria desenvolvida por esse autor, a qual se propõe a chamá-la de semântica global, Maingueneau (2008a) vai de encontro a princípios tradicionais de pensar a linguagem, ou seja, em um discurso, independentemente de seu gênero, todas as marcas aí encontradas são relevantes.

Portanto, a proposta desse autor é de que um discurso se caracteriza por uma semântica global, o que o leva a considerar o enunciado, isto é, o próprio texto, demonstrando assim que os gêneros textuais e suas formas de coesão são determinados pela semântica de uma formação discursiva.

Nessa perspectiva, a semântica global, sob o olhar de Maingueneau (2008a), refere-se a todos os conjuntos dos planos discursivos, quais sejam: a intertextualidade, o vocabulário, os temas, o estatuto de enunciador e do coenunciador, a dêixis enunciativa, o modo de enunciação e o modo de coesão. Cumpre destacar que, para esta seção, apoiamo-nos em estudos de Souza e Silva e Rocha (2009), autores que elaboraram uma resenha da obra de Maingueneau Gênese dos Discursos, que contribuiu sobremaneira neste estudo.

$\mathrm{O}$ primeiro plano refere-se à intertextualidade, a qual constitui "tipos de relações intertextuais que a competência discursiva define como legítimas" (MAINGUENEAU, 2008a, p. 77). É a intertextualidade, portanto, que deixa seus rastros por meio do intertexto, entendido como o conjunto de fragmentos efetivamente citados por um discurso. Ao falarmos em discurso literário, o conceito de intertextualidade é relevante à medida que a obra literária pode ser considerada o resultado de outras obras e de outros gêneros. Bakhtin (1992, p. 308) comenta que "um enunciado absolutamente neutro é impossível”. Observa-se, portanto, que a 
obra literária não é algo independente e solitária, mas o resultado de um diálogo e/ou a relação com outras obras e com os mais diversos gêneros do discurso.

No universo da semântica global, para Maingueneau (2008a), não faz sentido falar em vocabulário de tal ou qual discurso como se houvesse um léxico específico, mas sim em sentidos diferentes atribuídos a um mesmo item lexical por discursos diferentes. Logo, dependendo do posicionamento discursivo, "os enunciadores serão levados a utilizar aqueles que marcam sua posição no campo discursivo" (MAINGUENEAU, 2008a, p. 81). Nesse sentido, a literatura vale-se desses planos constituintes da semântica global, visto que os enunciadores fazem escolhas lexicais demarcando, assim, sua posição discursiva.

Lembramos, nesse momento, que o tema é outro elemento que faz parte do plano da semântica global. Em sentido amplo, é "aquele de que um discurso trata em qualquer nível que seja" (MAINGUENEAU, 2008a, p. 81). No entanto, os temas não devem ser tratados de maneira isolada ou estabelecer alguma hierarquia entre eles, pois sua ação é perceptível em qualquer ponto do texto. "À semelhança do vocabulário a especificidade de um discurso se define não por seus temas, mas por sua formação discursiva" (SOUZA-E-SILVA; ROCHA, 2009, p. 12, grifo dos autores).

Ainda, dentro dos planos constituintes da semântica global, conforme Maingueneau (2008a, p. 87, grifo do autor), "cada discurso define o estatuto que o enunciador deve se atribuir e o que deve atribuir a seu destinatário para legitimar seu dizer". No processo discursivo, há que se ter em mente que

[...] tanto o enunciador quanto o destinatário dispõem de um lugar e, nesse espaço, o enunciador projeta uma imagem de si no discurso a partir da qual o legitima (FREITAS; FACIN, 2011, p. 203).

O discurso comporta, ainda, de acordo com suas coerções semânticas, uma dêixis enunciativa que o situa no espaço e no tempo. A dêixis, em sua dupla modalidade, espacial e temporal,

[...] define de fato uma instância de enunciação legítima, delimita a cena e a cronologia que o discurso constrói para autorizar sua própria enunciação (MAINGUENEAU, 2008a, p. 89, grifo do autor).

No entanto, cumpre lembrar que a dêixis não implica marcas empíricas, mas estabelece uma cena e uma cronologia de acordo com coerções de determinadas formações discursivas.

Nesse contexto, o discurso caracteriza-se por uma maneira de dizer a qual Maingueneau (2008a) denomina modo enunciação. Nas palavras desse autor, o discurso

[...] produz um espaço onde se desdobra uma "voz" que lhe é própria. Não se trata de fazer um texto mudo falar, mas de circunscrever as particularidades da voz que sua semântica impõe (MAINGUENEAU, 2008a, p. 91).

Finalmente, o modo de coesão está relacionado à interdiscursividade e se dá pelo modo como um discurso constrói suas remissões internas, o que remete a 
[...] uma maneira que lhe é própria de construir seus parágrafos, seus capítulos, de argumentar, de passar de um tema a outro. Todas essas junturas de unidades pequenas ou grandes não poderiam escapar à carga da semântica global (MAINGUENEAU, 2008a, p. 96).

Pode-se observar, portanto, que a semântica global não tem a intenção de privilegiar um ou outro plano, mas sim promover o encontro de todos os planos no intuito de construir a cena enunciativa, tema que terá destaque na próxima seção.

\section{Cenografia e ethos no discurso literário}

É importante registrar, inicialmente, que os termos cenografia e ethos foram introduzidos por Maingueneau (1997), em sua teoria, na obra Novas Tendências em Análise do Discurso. Posteriormente a essa publicação, o autor passa a utilizar constantemente essas categorias teóricas nos seus textos.

Maingueneau (2009, p. 250), em sua obra Discurso Literário, comenta que, como todo enunciado, a obra literária implica uma situação de enunciação. No entanto, o próprio autor questiona “qual é a situação de enunciação de uma obra literária? Seria possível responder que são as circunstâncias de sua produção, sua situação de comunicação: ela foi escrita durante certo(s) período(s), em certo(s) lugar(es), por certo(s) indivíduo(s)". Contudo, destaca que essa seria uma resposta insuficiente, uma vez que convém apreender as obras não em sua gênese, mas como dispositivo de comunicação. Reduzir a situação de comunicação apenas à data e ao lugar de publicação é como permanecer no ato externo da comunicação literária.

Maingueneau esclarece ainda que,

[...] ao partir da situação de comunicação, considera-se o processo de comunicação, de certo modo, 'do exterior', de um ponto de vista sociológico. Em contrapartida, quando se fala de cena de enunciação, considera-se esse processo 'do interior', mediante a situação que a fala pretende definir (2009, p. 250, grifo do autor).

Dessa maneira, pode-se dizer que um texto configura-se por meio de "rastros de um discurso em que a fala é encenada" (MAINGUENEAU, 2009, p. 250).

Para entendermos melhor a noção de cena de enunciação, mais uma vez amparamos-nos nos estudos de Maingueneau (2009), o qual organizou a cena enunciativa em três dimensões: cena englobante, cena genérica e cenografia. “Juntas, elas compõem um 'quadro' dinâmico que torna possível a enunciação de um determinado discurso" (FREITAS, 2010 , p. 179). A cena englobante corresponde ao tipo de discurso, aquilo que o interlocutor, normalmente, costuma entender. De acordo com Maingueneau (2009), se nos entregam um folheto na rua, temos de relacioná-lo ao tipo de discurso que nos remete: se a um discurso religioso, político ou publicitário, etc. É o conteúdo do folheto que definirá o modo como o texto interpela o leitor. 
Ainda, segundo o autor,

[...] a cena englobante não é suficiente para especificar as atividades verbais, pois não se tem contato com o literário, político ou filósofo não especificado; a obra é na verdade enunciada através de um gênero do discurso determinado que participa num nível superior da cena literária (MAINGUENEAU, 2009, p. 251).

Desse modo, ao confrontar os diversos gêneros e os diferentes públicos, cada qual com suas expectativas, tem-se a cena genérica, que, juntamente com a cena englobante,

[...] definem o espaço mais ou menos estável no interior do qual o enunciado ganha sentido, isto é, o espaço do tipo e do gênero de discurso. Em muitos casos, a cena de enunciação reduz-se a essas duas cenas (POSSENTI, 2008, p. 204).

Além das cenas englobante e genérica, outra cena é capaz de intervir no discurso, a cenografia. Freitas e Facin (2011, p. 204) fazem referência a Maingueneau (2004), para destacar que

[...] a cenografia é construída pelo próprio texto e não diz respeito a um espaço físico, como se o enunciador pertencesse a um ambiente "emoldurado", mas, sim, a um espaço que é validado por meio da própria enunciação. A cenografia implica um processo de enlaçamento paradoxal entre as cenas, ou seja, a fala supõe uma situação de enunciação que é validada à medida que a própria enunciação se consolida.

A noção de cenografia está imbricada à noção do caráter teatral, o qual está associado à grafia. Essas duas noções garantem a legitimidade de um texto, ou seja, a obra se legitima criando um enlaçamento, fornecendo ao leitor um mundo cujo caráter exige que a própria cenografia represente aquilo que diz,
[...] logo, a cenografia é ao mesmo tempo origem do discurso e aquilo que engendra esse mesmo discurso; ela legitima um enunciado que, em troca, deve legitimá-la, estabelecer que essa cenografia de onde vem a fala é precisamente $a$ cenografia necessária para enunciar como convém (MAINGUENEAU, 2009, p. 253, grifo do autor).

Seguindo esse raciocínio, o autor chama a atenção para o fato de que

[...] a cenografia não é um "procedimento", o quadro contingente de uma "mensagem" que se poderia "transmitir" de diversas maneiras; ela forma unidade com a obra a que sustenta e que a sustenta (MAINGUENEAU, 2009, p. 253).

Podemos pensar também que, em uma cenografia, estão associadas a figura do enunciador e a figura do coenunciador, pois

[...] esses lugares supõem igualmente uma cronografia (um momento) e uma topografia (um lugar), das quais o discurso pretende originar-se (a cronografia e a topografia não são tempos cronológicos nem espaços geográficos, mas "tempos" e "espaços" ideológicos, históricos: a favela, a cidade, a civilização, a globalização) (POSSENTI, 2008, p. 205, grifos do autor).

A noção de cenografia também comporta a ideia de cenas validadas e cenas mostradas, as quais também são comuns no âmbito da literatura. Maingueneau (2009) esclarece a cena mostrada, citando as fábulas como o gênero que não diz de maneira explícita que seu conteúdo é um apelo a referências do mundo. No caso das fábulas, segundo o autor, são as marcas textuais de um texto que permitem essa percepção. Em relação às cenas validadas, as obras podem basear sua cenografia em cenas 
de enunciação já validadas, não necessariamente em gêneros literários, mas em outras situações de comunicações, como é o caso de um discurso político ou da fala de um camponês.

Para as situações de cena mostrada e de cena validada,

[...] não é preciso que a situação de enunciação mostrada pela obra esteja em perfeita consonância com as cenas validadas que ela reivindica em seu texto, nem que estas últimas formem um conjunto homogêneo (MAINGUENEAU, 2009, p. 257).

A cena total da obra consiste, portanto, em agregar todos esses elementos, e, desse modo, o que é mostrado em uma situação de enunciação somente toma corpo através da própria enunciação que a sustenta.

De acordo com o que preconiza a análise do discurso, o texto é o lugar de manifestação da materialidade do discurso. Mas, considerarmos a materialidade à luz da teoria de Maingueneau (2009) significa buscar dar conta de questões importantes para a compreensão das questões relacionadas à formulação, à circulação e à eventual eficácia dos textos.

$\mathrm{Na}$ concepção do autor, falar em cenografia não é falar em um simples alicerce, "uma maneira de transmitir 'conteúdos', mas o centro em torno do qual gira a enunciação" (MAINGUENEAU, 2009, p. 264). Ainda, conforme o autor, a literatura é um discurso cuja identidade se constitui através da negociação de seu próprio direito de construir; dito de outra forma, a cenografia de uma obra deve corresponder ao mundo que ela torna possível, seja por meio do contexto, seja pela cena de fala correlativa que atribui um lugar a seu leitor ou espectador, além de estar ativa e diretamente vinculada à configuração histórica na qual aparece.

Todas essas considerações feitas por Maingueneau (2009) remetem-nos a casos mais simples de uma obra literária, a qual é sustentada por uma única cenografia. Todavia, para esse autor, é possível considerar outras situações, especialmente as novelas, as quais, muitas vezes, são construídas com base no princípio da cenografia delegada, ou seja, o escritor evoca para um público indeterminado seu encontro com alguém que conta um evento notável, é uma situação em que a cenografia da obra não é nem do narrador extradiegético, nem a do narrador intradiegético, "mas a interação entre essas cenografias, cujas modalidades variam de acordo com as obras envolvidas" (MAINGUENEAU, 2009, p. 260). Diante de tais considerações, o autor ressalta, também, que a cenografia tem função integradora, e que integrar não significa definir uma configuração estável, ou seja, não há uma hierarquia clara entre as cenografias mostradas de uma obra, mas uma tensão entre duas cenografias colocadas no mesmo plano as que se mostram por meio das marcas textuais e a que se apresenta através do movimento da leitura.

Todo discurso implica uma apresentação, uma imagem de si mesmo, imagem que é construída por uma voz, um corpo próprio que remete à noção de ethos discursivo. O conceito de ethos é 
pesquisado e discutido desde a retórica de Aristóteles como uma forma de persuasão. Para Aristóteles, o ethos consiste em causar uma boa impressão diante do modo como se constrói o discurso e, assim, conquistar a confiança do auditório. Para isso, o filósofo estabeleceu três características necessárias ao orador: "a phronesis (prudência), a Arete (virtude) e a eunoia (benevolência)" (MAINGUENEAU, 2009, p. 267, grifo do autor). O orador precisava, por meio do discurso, emitir sua imagem. No entanto, o filósofo grego assegura que a conduta real do orador não garante que seu discurso implicará a adesão ou não do auditório. Desse modo, o que define o ethos é aquilo que é manifestado no discurso sobre o orador, sobre seu caráter.

Os estudos sobre ethos, de acordo com Maingueneau (2008b), passaram a interessar mais diretamente à linguística e à análise do discurso a partir de 1980, com as pesquisas desenvolvidas por Maingueneau e Ducrot. A partir de então, novos corpora foram estudados com o objetivo de ampliar pesquisas relativas a esse campo. Há de se reconhecer a noção híbrida do ethos e os problemas relacionados a ela, tais como a complexidade do efeito no discurso, o imbricamento de diversos fenômenos como ritmo e linguagem e a não garantia de que o ethos visado seja o produzido. Todos esses elementos são discutidos por Maingueneau (2009).

A noção de ethos, por mais simples que possa parecer, envolve múltiplas dificuldades.
O ethos está crucialmente ligado ao ato de enunciação, mas não podemos ignorar que o público constrói também representações do ethos do enunciador antes mesmo de ele começar a falar (MAINGUENEAU, 2009, p. 269 , grifo do autor).

Nesse sentido, o autor estabelece uma distinção entre ethos discursivo e pré-discursivo.

Maingueneau (2009) propõe que a imagem prévia que o público tem a respeito do orador também contribui para a formação do seu ethos efetivo, o que se caracteriza como ethos pré-discursivo. A construção feita sobre o orador pode induzir à construção de uma determinada imagem por parte de seu destinatário. Essa imagem, no entanto, pode ser desaprovada ou complementada a partir de traços linguísticos que se manifestam no discurso. Desse modo, ao falar de si mesmo, o sujeito deixa evidente algo sobre seu caráter, sua imagem e sua identidade.

O ethos de um discurso, no entanto, para Maingueneau (2009, 270, grifo do autor),

[...] resulta de uma interação de diversos fatores: o ethos pré-discursivo, o ethos discursivo (ethos mostrado), mas também os fragmentos do texto em que o enunciador evoca sua própria enunciação ethos dito, diretamente ("é um amigo que vos fala").

De maneira simples, entende-se o ethos dito como sendo aquele em que 0 enunciador sente a necessidade de falar de forma direta que "fulano de tal" é assim ou é isso, ou aquilo, enquanto o ethos mostrado revela-se no ato de enunciação por meio de marcas linguísticas, permanecendo em segundo plano na enunciação. 
No contexto da análise do discurso, com base nos postulados de Mainguene$\mathrm{au}$, o ethos refere-se a uma imagem de si por meio do discurso.

Dizer que os participantes do discurso criam uma autoimagem através dele significa também afirmar que o discurso carrega as marcas do enunciador e do coenunciador, entendidos aqui como aqueles que interagem no processo discursivo (FREITAS, 2010, p. 180).

Enquanto a retórica vincula o ethos discursivo essencialmente à oralidade, Maingueneau (2009, p. 271, grifo do autor) postula

[...] que todo o texto escrito, ainda que negue, possui vocalidade específica que permite remetê-lo a uma caracterização do corpo do enunciador (e não, está claro, do corpo do locutor extra discursivo), a um fiador que, por meio de seu tom, atesta o que é dito; o termo "tom" tem a vantagem de valer tanto para o escrito como para o oral.

Nessa perspectiva, Maingueneau (2009) admite que o ethos não abrange apenas a dimensão verbal, mas um conjunto de determinações físicas e psíquicas à qual ele institui como fiador. "Essa imagem é uma entidade abstrata que se constitui de duas propriedades: caráter e corporalidade" (FREITAS; FACIN, 2011, p. 206), pois

[...] o "caráter" corresponde a um feixe de traços psicológicos. Quanto à "corporalidade", ela é associada a uma compleição física e a uma forma de se vestir. Além disso, o ethos implica uma forma de mover-se no espaço social, uma disciplina tácita do corpo, apreendida por meio de um comportamento (MAINGUENEAU, 2008c, p. 65 apud FREITAS; FACIN, 2011, p. 206).

A enunciação, portanto, é que confere um corpo ao fiador, enquanto o coenunciador corresponde e assimila esse corpo.
Logo, essas incorporações juntas resultam na eficácia do discurso. Se por um lado a enunciação atribui um corpo ao fiador enquanto o coenunciador assimila esse corpo para tornar o discurso mais eficaz, por outro, Maingueneau (2009) designa o termo incorporação à maneira como o ouvinte ou leitor se apropria desse ethos. $\mathrm{O}$ autor recorre à etimologia empregando três registros para a incorporação, senão vejamos:

A enunciação da obra confere uma "corporalidade" ao fiador, dá-lhe um corpo, o destinatário incorpora, assimila um conjunto de esquemas que correspondem a uma maneira específica de se relacionar com o mundo habitando seu próprio corpo, essas duas primeiras incorporações permitem a constituição de um corpo, o da comunidade imaginária daqueles que aderem ao mesmo discurso (MAINGUENEAU, 2009, p. 272, grifo do autor).

Não é possível, portanto, dizer ou afirmar que o ethos apresenta-se da mesma forma em todos os textos. Freitas e Facin (2011, p. 201) lembram que "o ethos é característico e singular a cada gênero e tipo de discurso; logo, sua constituição compreende uma espécie de 'jogo' construído pela própria enunciação". Ainda, segundo esses autores, o ethos é "parte integrante da cena de enunciação e revela-se à medida que todos os planos são avaliados em determinado discurso. Estatuto de enunciador, coenunciador, dêixis discursiva e a própria escolha lexical são propriedades intrínsecas à construção da 'imagem de si”'.

Não se deve esquecer, no entanto, que o coenunciador seja unicamente um mero receptor de ideias, mas sim 
[...] alguém que tem acesso ao "dito" através de uma "maneira de dizer" que está 'enraizada' em uma "maneira de ser", o imaginário de um vivido (MAINGUENEAU, 1997, p. 49).

Freitas (2010, p. 180) destaca que

[...] o ethos liga-se ao orador, por meio, principalmente, das escolhas linguísticas feitas por ele, as quais revelam pistas acerca da linguagem do próprio orador, continuamente construída no âmbito discursivo.

Nessa perspectiva, buscamos analisar o romance Eva Luna como um discurso que possui voz e corpo próprios e em condições de levar o coenunciador a identificar-se com esse corpo, o qual é dotado de valores sócio-historicamente especificados. Na próxima seção, destacamos os dispositivos de análise que envolvem a construção do ethos discursivo, especialmente da personagem Eva do romance Eva Luna, de Isabel Allende (1994).

\section{Procedimentos metodológicos}

Este estudo, de caráter descritivo-qualitativo, apresenta como corpus o romance Eva Luna, da escritora chilena Isabel Allende. Na aplicação dos conceitos da teoria desenvolvida por Dominique Maingueneau (2008a), quanto aos planos constitutivos da semântica global, especificamente cenografia e ethos discursivo, nossa preocupação volta-se à questão norteadora descrita no início deste trabalho em razão de que todo discurso literário é configurado por uma cenografia, condição que valida a narrativa e define o estatuto de enunciador e coenunciador. Nesse particular, optamos pela realização da análise do discurso presente em dois capítulos do romance, sob a perspectiva da encenação do discurso da personagem Eva Luna, visto que o corpus nos viabiliza-nos tal proposta, pois as cenas enunciativas manifestadas nesse gênero - o romance - revelam marcas discursivas que nos permitem identificar a cenografia e, por conseguinte, o ethos discursivo.

No intuito de identificarmos essas "marcas discursivas" que instituem cenas de enunciação no romance $E v a$ Luna, buscamos na teoria proposta por Ginzburg (1989) a respeito do paradigma indiciário, meios para entender de que maneira essas pistas se configuram em um texto. Para esse autor, as raízes do paradigma indiciário remontam às origens da humanidade quando, por motivos de sobrevivência, o homem desenvolveu algumas habilidades baseadas em pistas. Durante anos o homem foi caçador e, para obter êxito em sua caçada, precisava identificar e/ou reconstruir perseguições a suas presas pelas marcas/pistas que essas deixavam, como pegadas na lama, bolotas de esterco, tufos de pelos, ramos quebrados, entre outros. Assim, o homem aprendeu a farejar, registrar, interpretar e fazer uma "leitura" dessas pistas para reconstruir, através de indícios, o aspecto de um animal nunca visto. "Decifrar" ou "ler" as pistas dos animais são metáforas que 
Ginzburg (1989, p. 152) usa para a "condensação verbal de um processo histórico que levou, num espaço de tempo talvez longuíssimo, à invenção da escrita".

Ginzburg (1989, p. 145), ao lembrar do método indiciário proposto por Castelnuovo, comenta que "o conhecedor de arte é comparável ao detive que descobre o autor do crime (do quadro) baseado em indícios imperceptíveis para a maioria". Essa abordagem metodológica de análise qualitativa, defendida por Ginzburg (1989), remete-nos à seguinte passagem do romance em estudo:

[...] haverá eleições dentro de vinte dias. O próximo presidente procurará dar uma impressão de liberalidade e será prudente com a censura. De qualquer modo, sempre se pode alegar que é tudo ficção e, sendo a telenovela muito mais popular que o noticiário, todos saberão o que ocorreu em Santa Maria (ALLENDE, 1994, p. 316-317).

A partir dessa passagem e retomadas as considerações a respeito das marcas/ pistas que o autor deixa no texto, às quais Ginzburg (1989) refere-se, percebemos ser possível identificar essas marcas no romance em estudo, pois a época em que a autora escreveu a obra Eva Luna foi aquela em que escritores, compositores, radialistas e jornalistas precisavam utilizar frequentemente essas marcas/ pistas, a fim de não sofrerem represálias do governo.

Quanto aos objetivos traçados, esta pesquisa é descritiva, a qual, consoante Prodanov e Freitas (2009, p. 63), "procura classificar, explicar e interpretar fatos que ocorrem". Em relação aos pro- cedimentos técnicos, nossa pesquisa é de cunho bibliográfico, uma vez que sua base se dá na consulta a materiais já publicados a respeito das teorias-base, em livros, artigos científicos, dissertações e teses. Este estudo é, ainda, quanto à forma de abordagem da questão norteadora, qualitativo, pois

[...] considera que há uma relação dinâmica entre o mundo real e o sujeito, isto é, um vínculo indissociável entre o mundo objetivo e a subjetividade do sujeito que não pode ser traduzido em números (PRODANOV; FREITAS, 2009, p. 81).

Esse tipo de pesquisa permite uma nova leitura, uma vez que, para os autores, requer "a interpretação dos fenômenos e atribuição de significados, premissas básicas dessa modalidade de abordagem e interpretação". A seguir, descrevemos uma sinopse do romance, observando que, pelas limitações de extensão deste trabalho, faremos a análise relativa a dois capítulos da obra, os quais nos possibilitaram identificar mais claramente as cenografias e ethé depreendidos do discurso da narrativa.

\section{Eva Luna: sinopse}

A personagem Eva Luna nasce de uma relação casual entre a mãe, Consuelo, e um índio. Após a morte da mãe, Eva passou a ser cuidada pela madrinha, mas aos 8 anos começa a trabalhar para sustentar-se. Aos 15 anos Eva já experimentara os dissabores do desemprego e a vida nas ruas. O desprezo e a humilhação pela qual passou 
desencadearam na menina um desejo muito grande em conquistar espaços maiores. Riad Halabí encontra Eva na rua e a leva para viver com ele e a esposa em uma pequena aldeia chamada Água Santa. Riad deu-lhe um registro de nascimento, ensinou-lhe a fazer contas e contratou uma professora para ensinar-lhe a ler e a escrever. De volta à capital, Eva reencontra Huberto Naranjo, um ex-menino de rua e que agora se transformara em chefe da guerrilha, e Melécio, um transexual que conhecera há alguns anos e que percebe o dom da menina com as palavras, incentivando-a a escrever. Nesta época viviam no período da ditadura militar, portanto, pouco se podia dizer. Diante dessa nova realidade, Eva teve a ideia de contar a verdade a respeito do que ocorria nos bastidores do governo a partir da telenovela Bolero. A partir da apropriação da palavra, Eva Luna supera diferentes problemas desde a infância, com a orfandade, a exploração e a violência, fazendo ouvir a voz ${ }^{4}$ feminina em um mundo dominado pelo sistema patriarcal.

\section{Análise do corpus - capítulos três e onze}

Capítulo 3 (49-85) - A morte de Consuelo e o drama de Eva: início

No capítulo três, Eva narra como Consuelo, sua mãe, engasgou-se com um osso de galinha na noite de natal. Nessa época, Eva tinha apenas seis anos de idade, mas lembra com detalhes da morte da mãe "quando compreendeu que a vida ia embora, trancou-se comigo em nosso quarto do pátio, para ficarmos juntas até o fim" (p. 50) $)^{5}$. Consuelo preparou-se para morrer, lavou-se com água e sabão, a fim de desprender-se do odor de almíscar, penteou a comprida trança, vestiu uma anágua e deitou-se. Eva não entendeu muito bem o significado de tal cerimônia, mas observava atenta aos detalhes. "A morte não existe, filha. A gente só morre quando nos esquecem - explicou, pouco antes de partir. - Se você puder lembrar-se de mim, estarei sempre ao seu lado. - Eu me lembrarei - prometi" (p. 50).

Após a morte de Consuelo, Eva passou a ser cuidada pela madrinha, outra empregada da mansão do professor Jones. Aos oito anos, a menina começou a trabalhar em casa de família, pois sua madrinha alegava que não podia mais cuidá-la. "Se você fosse homem, iria para a escola, depois começaria a estudar para advogado, assegurando assim o pão da minha velhice. Eles é que mais ganham, sabem enrolar as coisas" (p. 52).

Essa passagem narrativa evidencia uma cenografia da qual se depreende o ethos discursivo da madrinha de Eva, pois, pelo discurso, percebe-se claramente que a madrinha subestima a capacidade e a inteligência não apenas da afilhada, mas das mulheres em geral, se você fosse homem [...] e, eles é que mais ganham. No primeiro emprego de Eva, ao entregá-la à patroa, a madrinha reforça seu ethos discursivo, ou seja, 
sua maneira de ser e sua maneira de dizer dando as últimas recomendações: "não seja mal criada, cuidado para não quebrar alguma coisa [...], porte-se bem e obedeça" (p. 62).

De acordo com Maingueneau (2008b), o ethos não abrange apenas a dimensão verbal, mas um conjunto de determinações físicas e psíquicas à qual esse autor instituiu como fiador, no caso, a madrinha. Cabe destacar que essa imagem corporal do enunciador resulta na figura do fiador,

[...] entendida aqui como aquela que deriva da representação do corpo de enunciador efetivo (e não, bem entendido, do corpo do autor efetivo), se construindo no âmbito do discurso (FREITAS, 2010, p. 180).

Observa-se, nesse capítulo, a instituição de uma cenografia por meio do discurso da mãe de Eva quando Consuelo se prepara para morrer, " $a$ gente só morre quando nos esquecem" e por meio do discurso da madrinha "se você fosse homem, iria para a escola, depois começaria a estudar para advogado". Os discursos da mãe e da madrinha configuram uma cenografia em um espaço que é moldado pela própria enunciação, ou seja, a cenografia estabelece uma relação paradoxal entre as cenas, pois, para Maingueneau (2008c, p. 77), "a fala supõe uma certa cena de enunciação que, de fato, se valida progressivamente por essa mesma enunciação".

A cenografia construída nesse capítulo 3 do romance Eva Luna configura o ethos da madrinha, uma pessoa descrente e conformada com o que a vida lhe oferece.
Percebe-se, também, que a atitude da madrinha condiz com a realidade das mulheres em um passado recente, isto é, era comum para as mulheres assumirem uma posição de submissão e inferioridade em uma sociedade em que predominava 0 sistema patriarcal. A madrinha não acreditava na força e na capacidade do sexo feminino. Para ela, somente os homens são capazes de vencer na vida, seja pelo estudo, seja pela profissão. À mulher cabe apenas um universo sem vez e sem voz.

$$
\text { Capítulo } 11 \text { (281-324) - Eva }
$$

Luna: uma história, um desafio

\section{para contar}

Este capítulo trata basicamente de três temas: um massacre de prisioneiros ocorrido em um Centro de Operações do Exército de um país cujo nome não consta na obra, a fuga de um grupo de guerrilheiros de uma penitenciária e o lançamento da novela Bolero que Eva escreveu.

Como o foco do nosso trabalho é analisar o discurso no texto literário, mais especificamente no que diz respeito à construção da cenografia e do ethos discursivo, planos constitutivos da semântica global, o capítulo 11 nos pareceu adequado, especialmente no que se refere à situação de enunciação, pois, de acordo com Maingueneau (2009, p. 250), "como todo enunciado, a obra literária implica uma situação de enunciação". Assim, percebemos, por intermédio da formação discursiva instituída no capítulo sob análise, a construção de uma imagem de um grupo de guerrilheiros 
que, embora cientes de que seu ideal era uma batalha impiedosa, tinha um único objetivo: lutar por um mundo melhor e mais igualitário e vingar o massacre de dezenas de prisioneiros, método empregado pelo governo para combater a guerrilha. Dessa maneira, identificamos o processo que envolve os sujeitos da enunciação. Huberto Naranjo e Eva Luna unem suas forças, coragem e determinação para libertar um grupo de guerrilheiros presos pelo Exército. Destacamos o excerto discursivo que segue:

Mimi entrou no quarto para desejar-me boa-noite, como sempre fazia, e surpreendeu-me desenhando linhas em uma folha de papel. Quis saber do que se tratava. Não se meta em confusões! Exclamou aterrada, ao saber do projeto. Tenho que fazer isso, Mimi. Não podemos continuar ignorando o que acontece no país (p. 285).

Eva ignorou as súplicas de Mimi e embarcou em mais uma aventura, a fim de colaborar com Naranjo na fuga dos guerrilheiros. Para colocar o plano em prática, inicialmente coube à Eva a tarefa de fornecer a Huberto um mapa da fábrica de uniformes militares onde ela havia trabalhado. A segunda missão de Eva foi a fabricação da matéria universal (aprendida com uma antiga patroa), uma espécie de granada, de ingredientes simples, porém de poder devastador e semelhante à usada no Exército. Eva convence Mimi de que é preciso parar com o conformismo e aceitar as regras do governo, cujos beneficiários eram um pequeno grupo de pessoas, em geral, ligados ao próprio governo.
Éramos dois seres marginais, condenados a lutar por cada migalha, que embora rompêssemos as cadeias que nos prendiam desde o dia de nossa concepção, ainda restariam as paredes de um cárcere maior; não se tratava de modificar as circunstâncias pessoais, mas de mudar toda a sociedade (p. 286).

Ao demonstrar esse objetivo comum, o qual tinha como representante Huberto Naranjo ou o Comandante Rogélio, institui-se na cenografia a voz de $\mathrm{Hu}$ berto e de Eva que partilham do mesmo desejo do coenunciador, a sociedade: não se tratava de modificar as circunstâncias pessoais, mas de mudar toda a sociedade. Desse modo, cria-se uma imagem coletiva de um grupo da sociedade, os "marginalizados e excluídos da história" que lutam com entusiasmo e esperança por melhores condições de vida, mas também que contemple o maior número possível de cidadãos, especialmente os que pertencem às classes menos favorecidas.

É sob essa perspectiva que "cada discurso define o estatuto que o enunciador deve se atribuir e o que deve atribuir a seu destinatário para legitimar seu dizer" (MAINGUENEAU, 2008a, p. 87, grifo do autor). Assim, o enunciador (grupo de guerrilheiros) atribui-se o estatuto de um grupo que deseja uma sociedade mais justa. Dessa maneira, é possível depreendermos, discursivamente, nesse capítulo, uma imagem que Allende faz do contexto sócio-histórico em que a obra foi escrita: o período da ditadura militar na América Latina. Eis a cenografia constituída, da qual deriva o ethos do governo, opressor, violento e autoritário. 
Após a libertação dos guerrilheiros, o governo envergonhado e receoso de que a verdade viesse à tona permitiu que o diretor da penitenciária desse uma declaração "falsa", alegando que "um grupo terrorista efetuara o assalto com helicópteros, armados de bazucas e metralhadoras, enquanto no interior do recinto os delinquentes neutralizavam os guardas a bombas" (p. 313). A execução do plano do comandante Rogélio foi registrada pelo cineasta Rolf Carlé, que pretendia, em algum momento e de alguma forma, desmascarar o governo e o Exército, pois a versão dada à população pela Televisão Nacional não passava de mais uma farsa do governo.

A invasão à penitenciária deu origem a vários rolos de filme e à notícia mais alucinante dos últimos anos.

\footnotetext{
Alegro-me por eles, mas não sei de que adiantam os filmes para você, se tudo isso está censurado. - Iremos mostrá-los - respondeu Rolf. - Sabe muito bem que espécie de democracia é esta, Rolf. Com o pretexto do anticomunismo, não temos mais liberdade do que nos tempos do General...-Se não nos permitirem dar a notícia, tal como fizeram com a matança no Centro de Operações, contaremos a verdade na próxima telenovela.Quê? - A que você escreveu irá para o ar tão logo termine essa idiotice da cega e do milionário. Terá que dar um jeito para encaixar a guerrilha e o assalto à Penitenciária em seu enredo. Tenho uma mala de filmes sobre a luta armada. Muito disso poderá servir-lhe. Jamais permitirão... (p. 316).

O desejo de que a verdade prevaleça é materializado por meio de alguns indícios textuais: Se não nos permitirem dar a notícia, tal como fizeram com a matan-
}

ça no Centro de Operações, contaremos a verdade na próxima telenovela. Dessa maneira, o tom enunciativo que Rolf usa revela uma postura de alguém disposto a não se calar mais em relação ao autoritarismo do governo. Ao evocar essa "maneira de dizer" a qual é chamada de modo de enunciação por Maingueneau,

[...] o discurso produz um espaço onde se desdobra uma 'voz' que lhe é própria. Não se trata de fazer um texto mudo falar, mas de circunscrever as particularidades da voz que sua semântica impõe (MAINGUENEAU, 2008a, p. 91).

Ainda, segundo esse autor, o termo modo de enunciação remete à "reflexão sobre a 'voz', a 'oralidade', o 'ritmo' de cada discurso". Esse discurso assume a cenografia de uma sociedade cansada da repressão e das imposições governamentais, cujo ethos caracteriza-se pelo otimismo, persistência, determinação e vingança. Essa passagem discursiva lembra-nos de que, ao ler um texto literário, não estamos diante de uma cena englobante, mas sim de uma cenografia que, no universo literário, articula a obra de modo independente, possibilitando a construção da própria identidade.

Além da cena englobante, cena genérica e da cenografia que sustentam a obra literária, há outros casos os quais Maingueneau (2009, p. 260) denomina de "fenômeno da 'narração intradiegética' em que o narrador delega a função a uma personagem da narrativa". Observemos a seguinte passagem: 
[...] haverá eleições dentro de vinte dias. O próximo presidente procurará dar uma impressão de liberalidade e será prudente com a censura. De qualquer modo, sempre se pode alegar que é tudo ficção e, sendo a telenovela muito mais popular que o noticiário, todos saberão o que ocorreu em Santa Maria. E eu? A polícia me perguntará como fiquei sabendo tudo isso... Ninguém tocará em você, porque equivaleria a reconhecerem que está dizendo a verdade - replicou Rolf Carlé (p. 316-317).

A experiência vivida pela escritora (enunciador) no período da ditadura militar permite-nos inferir que Allende delega (cenografia delegada) à Eva a missão de retratar a realidade e denunciar as atrocidades dos que detinham o poder, uma vez que a escritora como uma cidadã comum não podia fazê-lo, de qualquer modo, sempre se pode alegar que é tudo ficção e, sendo a telenovela muito mais popular que o noticiário, todos saberão o que ocorreu em Santa Maria. Assim, o desejo da escritora (enunciador) revela, por meio da narrativa, uma maneira de dizer e uma maneira de ser através do discurso literário. Diante disso, a postura do enunciador (Eva), determinada a contar a história de seu país assume a condição de sujeito responsável pelo discurso.

De acordo com Maingueneau (2008a, p. 87, grifo do autor), "cada discurso define o estatuto que o enunciador deve atribuir a seu destinatário para legitimar seu dizer". Esse enunciador, no caso Eva Luna, portanto, atribui-se o estatuto de alguém que deseja denunciar a verdade, pois está cansada de ignorar, como tantos outros, as injustiças sociais. Para isso, usa os únicos instrumentos de que dispõe, o domínio da palavra e a ficção.

Prudente, Eva aguarda as eleições presidenciais, as quais transcorreram "em ordem e entusiasmo como se o exercício dos direitos republicanos fosse um longo hábito, em vez do milagre mais ou menos recente, como realmente era" (p. 317). A vitória, como previsto, coube ao candidato da oposição, ao mesmo tempo que chegara ao fim a novela que entediara a todos durante quase um ano. Eva Luna finalmente pode contar a história, que, por muito tempo, guardara na memória.

Tão logo terminou a novela da cega e do milionário, os telespectadores da Televisão Nacional foram surpreendidos com "Bolero", a novela que Eva estava escrevendo e que, de uma maneira descontraída, porém não sem a seriedade necessária, mostrava ao público uma verdade sobre o que ocorria nos bastidores do governo, jamais vista naquele país. O enunciador, Eva, ao falar por meio da ficção, tenta passar uma imagem de si ao coenunciador (telespectadores).

O público foi tomado de surpresa já no primeiro capítulo, não conseguindo refazer-se do aturdimento nos seguintes. Acho que ninguém entendeu qual o rumo daquela história disparatada, pois estavam todos acostumados aos ciúmes, despeito, ambição, ou pelo menos à virgindade, mas nada disso aparecia em suas telas, e iam dormir cada noite com a alma perturbada (p. 317-318).

Destacamos que a cenografia instituída no capítulo 11 constitui-se sob a forma de uma imagem extremamente negativa do governo por usar a violência, a repressão e a força contra a população 
de seu país. Note-se que o destinatário incorpora, com base em indícios linguísticos fornecidos pelo enunciador, uma imagem desse enunciador. Temos, então, o ethos construído.

Durante uma semana, foi tamanho o transtorno causado pelas inundações, que a imprensa não falou em outra coisa. Se não fosse por Rolf Carlé, o massacre em um Centro de Operações do Exército teria passado quase desapercebido, sufocado nas águas turvas do dilúvio e bastidores do poder. Um grupo de presos políticos amotinou-se, e após apoderar-se das armas de seus guardiães, entrincheirou-se em um setor dos pavilhões. O Comandante, homem de iniciativas rápidas e ânimo sereno, não solicitou instruções simplesmente ordenando que os amotinados fossem pulverizados. Suas palavras foram tomadas ao pé da letra. Os prisioneiros foram atacados com armamento bélico, um número indeterminado de homens foi morto e não houve feridos, porque reuniram os sobreviventes no pátio e lá os liquidaram sem clemência. Quando passou a embriaguez de sangue dos guardas eles contaram os cadáveres, compreenderam que seria difícil explicar sua ação à opinião pública e tampouco poderiam enganar os jornalistas, alegando que se tratava de rumores infundados (p. 281).

Para escrever a novela Bolero, Eva conta não apenas com o dom que lhe é peculiar para contar histórias, mas com a colaboração de outros personagens, cada um a seu modo que, ao longo desse capítulo, ajudaram-na a construir a história de um povo sofrido e massacrado pelo poder público. A partir de Bolero, Eva evidencia seu ethos discursivo, pois a coragem, a confiança e a determinação da protagonista se sobrepõem às regras do governo. No entanto, cabe ressaltar que no capítulo em questão há outros personagens marcantes os quais são caracterizados pela rebeldia, atrevimento e determinação de Huberto Naranjo e pela coragem, otimismo e persistência de Rolf Carlé ao arriscar-se com suas câmeras, registrando o que conseguia, como prova da repressão e das atrocidades do governo. As atitudes de Eva, Huberto e Rolf são o testemunho de que os jovens estavam dispostos a enfrentar o governo e as autoridades por um mundo melhor, inclusive, mostrando ao país e ao mundo que à mulher não caberia mais apenas a obediência e o silenciamento, pois a protagonista subverte os padrões convencionais impostos pela sociedade.

A fim de verificar se as cenografias e ethé discursivos identificados na obra, de modo geral, coincidem com as cenografias e ethé dos capítulos analisados, sobretudo se esses elementos constitutivos da semântica global são reincidentes e integrados entre si, elaboramos o Quadro 1 para constatar e confrontar tais elementos na materialidade linguística. 
Quadro 1: Comparativo entre cenografias e ethé da obra em consonância aos capítulos analisados

Cenografias identificadas na obra

A construção de uma imagem que a escritora faz do contexto sócio-histórico em que a obra foi escrita: o período da ditadura militar na América Latina, na década de 1970. A cenografia maior da obra revela uma imagem negativa do governo em relação à população em geral, especificamente os excluídos da sociedade. Também é possível perceber a luta da personagem Eva Luna por meio do uso da palavra/do discurso, por um mundo onde a igualdade entre homens e mulheres fosse possível e pelos direitos que julga serem também do sexo feminino, ou seja, o de ter voz em uma sociedade de domínio masculino.

Ethé discursivos identificados na obra

* Os ethé identificados são bem definidos para o sexo masculino e feminino:

- Masculinos: determinados, autoritários, dominadores, vingativos, atrevidos, corajosos, otimistas e persistentes.

- Femininos: descrentes, conformistas, comodistas, passivas, submissas, e sensatas.

- Eva Luna: inocência, pureza, confiante, rebelde, inconformada, determinada e audaciosa.
Cenografias identificadas nos capítulos 3 e 11

\section{Cap. 3}

- o ritual de Consuelo antes de morrer;

- Eva passa a ser cuidada pela madrinha e começa a trabalhar em casas de família.

Cap. 11

- o massacre dos prisioneiros;

- a fuga dos guerrilheiros da Penitenciária de Santa Maria;

- o lançamento da novela Bolero.
Ethé discursivos identificados nos capítulos 3, e 11

\section{Cap. 3}

- Madrinha, descrente e conformada;

- Eva, inocência e pureza;

- Consuelo, conformada, comodista, passiva e submissa.

Cap. 11

- governo, repressor, violento e autoritário;

- Huberto Naranjo, determinado, vingativo, prepotente e atrevido;

- Rolf Carlé, corajoso, otimista e persistente;

- Mimi, satisfeita, discreta e sensata;

- Eva Luna, confiante, rebelde, inconformada, determinada e audaciosa.

Fonte: elaborado pelos autores.

A partir das marcas linguísticas presentes no discurso, à luz dos preceitos da semântica global, constatamos, no romance Eva Luna, mais especificamente nos dois capítulos analisados, as cenografias e os respectivos ethé discursivos instituídos por essa abordagem linguístico-discursiva. Para que tal constatação fosse possível, centramo-nos em conceitos delimitados no referencial teórico.

Diante do exposto, verificamos que há relação entre as cenografias e ethé 
identificados na obra, em seu âmbito geral, em conformidade com os capítulos analisados. Na sequência, registramos as considerações finais deste estudo, de modo a contemplar a teoria estudada em relação com o corpus de pesquisa.

\section{Considerações finais}

A proposta, neste artigo, foi constituir uma interface entre a teoria enunciativo-discursiva e a escrita literária, mais especificamente descrever e analisar o ethos discursivo depreendido de dois capítulos do romance Eva Luna, de autoria da escritora chilena Isabel Allende.

$\mathrm{Na}$ primeira seção, nossas reflexões voltaram-se para a importância da leitura como processo de comunicação e de interação verbal e social na vida do ser humano. Considerando a relevância do ato de ler na vida do sujeito, descrevemos alguns aspectos relacionados à leitura versus literatura. Para tanto, contamos com as contribuições de Bakhtin (1992), Barthes (2004), Bordini e Aguiar (1988), Kleimann (1999), Koch (1984) e Zilberman (1999).

Diante desse contexto de estudo e da pesquisa realizada, retomamos a temática deste trabalho, a qual se insere nos pressupostos da teoria enunciativo-discursiva de Dominique Maingueneau (1997, 2008a, 2009, 2010) e da escrita literária, também conforme Maingueneau (2009), em especial, para descrever e analisar a construção da cenografia e do ethos discursivo depreendidos nos capítulos três e onze do romance.

Ao selecionarmos o corpus de pesquisa, partimos da premissa de que todo discurso literário é configurado por uma cenografia cuja condição é validar a narrativa, ao mesmo tempo em que define o estatuto do enunciador e do coenunciador. Pensando nessa perspectiva, a questão norteadora estabelecida levou-nos a verificar se os dois capítulos do romance Eva Luna permitiriam descrever e analisar a cenografia e o ethos discursivo, considerando as particularidades da escrita literária.

Optamos por esmiuçar como se constrói a cenografia e o ethos discursivo da personagem principal do romance, a fim de estabelecer uma relação entre estudos linguísticos e literários, cujo texto, em sua narrativa, é analisado pelo viés da semântica global de Maingueneau (2008a). Mediante esse objetivo teórico, propusemos constituir uma interface entre a teoria enunciativo-discursiva e a narrativa em texto literário. Assim, entendemos, por decorrência do estudo realizado, que é possível depreender cenografia e respectivo ethos do romance com base no que fora desenvolvido e apresentado ao longo deste artigo.

O objetivo geral deste trabalho consistiu em descrever e analisar o ethos discursivo da personagem principal no romance Eva Luna através do desenvolvimento da narrativa, mediante a qual se tornou possível depreender, da discursivização observada na narrativa como um todo e dos capítulos analisados, as 
cenografias construídas que resultaram variados ethé discursivos. Considerando as particularidades da escrita literária à luz da semântica global, o objetivo geral ao qual nos propomos, portanto, foi cumprido. Alcançamos também, por meio dos dispositivos de análise, os objetivos específicos.

Procedemos a um estudo dos elementos que constituem a semântica global de Maingueneau (1984/2008a): intertextualidade, vocabulário, tema, estatuto de enunciador e de coenunciador, dêixis enunciativa, modo de enunciação e o modo de coesão. Desse modo, compreendemos a situação de enunciação na narrativa mediante a forma como foram construídas as cenografias e os respectivos ethé discursivos na voz da personagem Eva Luna.

A construção da cenografia deu-se a partir de uma imagem que a escritora faz do contexto sócio-histórico no período da ditadura militar na América Latina, na década de 1970, época em que a obra foi escrita. Em relação aos capítulos analisados, constatamos que esses são reincidentes e integrados entre si, uma vez que o desejo da escritora em denunciar as atrocidades do governo de seu país é revelado por meio da ficção. Ao alternar os temas nos capítulos da obra, Allende consegue transmitir ao leitor uma visão geral da sociedade da época ditatorial.

Ao procedermos à compreensão de como se constroem os diferentes ethé discursivos, representados nas cenas de enunciação, as escolhas linguísticas utilizadas pela escritora nos permitiram identificar o ethos de forma particularizada dos personagens masculinos e femininos com destaque especial ao ethos da personagem Eva Luna.

A constituição da cenografia enunciativa foi identificada com base em pistas/ marcas deixadas no texto. Nesse sentido, destacamos que o tempo e o espaço de uma cena, bem como as imagens de enunciador e coenunciador configuram-se na cenografia. Nesse particular, observamos que o romance em estudo apresenta riqueza de detalhes que nos permitiram identificar a cenografia da qual, consequentemente, deriva o ethos discursivo das personagens, como verificado na análise de maneira geral e particularizada.

Quando nos propusemos a analisar a cenografia e o ethos depreendidos no romance, fizemo-lo primeiro por entender que estudos literários e estudos linguísticos não devem ser estudados separadamente, como na situação aqui proposta: a interdisciplinaridade. Sobre as possíveis limitações desta pesquisa, podemos dizer que são de ordem quantitativa levando-se em conta o corpus deste estudo, um romance, cuja quantidade de conteúdos existentes e possíveis de análise é muito extensa, permitindo-nos, dessa forma, cumprir os objetivos e aplicar a metodologia desenvolvida. Obviamente que, pela extensão do corpus, poderíamos ter feito outras análises; todavia, este espaço, não nos possibilita muitas delongas.

Este trabalho, também, viabilizou reconhecer que a literatura somente 
constrói sua identidade pelo discurso, por uma cenografia que lhe é própria. Todavia, trata-se de um estudo particular, pois certamente não foram abordadas todas as possibilidades possíveis propostas pela teoria enunciativo-discursiva, semântica global de Maingueneau (2008a), por serem abrangentes, e ao mesmo tempo específicas, para um trabalho como este. Apesar dos vários estudos sobre o romance Eva Luna, entendemos este como inovador no que se refere à interface entre linguística e literatura e quanto às reflexões acerca da cenografia e do ethos discursivo depreendidos desta obra. No entanto, não foi nossa intenção tornar essa pesquisa como algo acabado, mas uma motivação a mais no que diz respeito à interface entre estudos linguísticos e literários.

Por fim, destacamos que nossa pretensão não foi esgotar o assunto; ao contrário, trata-se de uma contribuição inicial a estudos futuros. Fica a sugestão para que novas pesquisas sejam realizadas envolvendo outras teorias que também busquem a interface entre linguística e literatura, porque a entendemos como produtiva e promissora, uma vez que os fatos linguístico-discursivos se fazem presentes em ambos os enfoques: linguístico e literário.
The scenery in literary discourse: expository bonding and ethos in the novel Eva Luna

\begin{abstract}
It is still common to find a certain distance between the academic areas of Linguistics and Literature. However, some scholars of language are beginning to realize these two aspects as intertwined with each other, since, on one side we have linguistics studies devoted to texts characterized as non-literary and, on the other side, literature, responsible for exploring the aesthetic order of works. Given the interdisciplinary scenario, the aim of this study turns to describe and analyze the discursive ethos of the main character of the novel Eva Luna, considering that literary discourse is configured by a scenography, whose condition is to validate the narrative at the same time that defines the enunciator and co-enunciator status inside the situation of enunciation that features the scenography instituted in the scenery speech. The theoretical approach of this study fall into the perspective of discursive analysis of French line, more specifically in the discursive-enunciative device proposed by Dominique Maingueneau (1997, 2008a, 2009, 2010) and his students, including Possenti (2008), Souza-e-Silva and Rocha (2009), and Freitas and Facin (2011). The theoretical-methodological procedures of analysis are anchored in the concepts of scenography and discursive ethos identified by linguistic-discursive marks in the literary text Eva Luna. The research showed that the discursive ethos identifies through enunciative scenes
\end{abstract}


built, which give the character Eva the quality of sponsor inside of the analyzed narrative.

Keywords: Novel. Eva Luna. Isabell Allende. Scenography. Discursive ethos.

\section{Notas}

1 Para este trabalho, utilizamos a edição de 1994.

2 Em função de sua dupla origem, o termo "formação discursiva" obteve grande êxito, mesmo fora dos trabalhos inspirados pela Escola* Francesa. Esse permite, com efeito, designar todo conjunto de enunciados sócio-historicamente circunscrito que pode relacionar-se a uma identidade enunciativa (CHARAUDEAU; MAINGUENEAU, 2008, p. 241-42).

3 Maingueneau (2009, p. 260) observa que além da cena englobante, cena genérica e da cenografia que sustentam a obra literária, há outros casos, os quais esse autor denomina de 'fenômeno da 'narração intradiegética', em que o narrador delega a função a uma personagem da narrativa".

4 A partir da análise, utilizamos os números entre parênteses para identificar as páginas que correspondem a cada capítulo analisado no romance.

5 Entendemos que Isabel Allende faz ouvir/“aparecer" a mulher latino-americana, cuja voz tem sido, muitas vezes, abafada, dando à personagem Eva a possibilidade de falar pela escritora.

\section{Referências}

ALLENDE, Isabel. Eva Luna. Tradução de Luísa Ibañes. 4. ed. Rio de Janeiro: Bertrand Brasil, 1994.

BAKHTIN, Mikhail. Estética da criação verbal. São Paulo: Martins Fontes, 1992.

BARTHES, Roland. O rumor da língua. São Paulo: Martins Fontes, 2004.
BORDINI, Maria da Glória; AGUIAR, Vera Teixeira de. Literatura: a formação do leitor - alternativas metodológicas. Porto Alegre: Mercado Aberto, 1988.

CHARAUDEAU, Patrik; MAINGUENEAU, Dominique. Dicionário de Análise do Discurso. São Paulo: Contexto, 2008.

ECO, Humberto. Sobre a literatura. Trad. Sulla Letteratura. Rio de Janeiro: Record, 2003.

FIORIN, José Luiz. Seminários especiais. Passo Fundo: Universidade de Passo Fundo, 2011. Disciplina ministrada em $15 \mathrm{dez} .2011$ na Universidade de Passo Fundo.

FREITAS, Ernani Cesar de. Linguagem na atividade de trabalho: éthos discursivo em editoriais de jornal interno de empresa. $D e$ senredo, Passo Fundo, v. 6, n. 2, p. 170-197, jul./dez. 2010.

FREITAS, Ernani Cesar de; FACIN, Débora. Semântica global e os planos constitutivos do discurso: a voz feminina na literatura de Rubem Fonseca. Desenredo, Passo Fundo, v. 7, n. 2, p.198-218, jul./dez. 2011.

GINZBURG, Carlo. Mitos, emblemas, sinais. Trad. Federico Carotti. São Paulo: Companhia das Letras, 1989.

KLEIMAN, Ângela. Texto e leitor: aspectos cognitivos da leitura. Campinas: Pontes, 1999.

$\mathrm{KOCH}$, Ingedore Grunfeld Vilaça. Argumentação e linguagem. São Paulo: Cortês, 1984.

MAINGUENEAU, Dominique. Pragmática para o discurso literário. Trad. Marina Appenzeller. São Paulo: Martins Fontes, 1996.

Novas tendências em Análise de Discurso. Trad. Freda Indursky. Campinas: Pontes, 1997.

. Análise de textos de comunicação. 2. ed. Tradução de Cecília P. de Souza-e-Silva e Décio Rocha. São Paulo: Cortez, 2002. 
. Análise de textos de comunicação. Trad. de Cecília P. de Souza-e-Silva e Décio Rocha. São Paulo: Cortez, 2004.

. (1984). Gênese dos discursos. Tradução de Sírio Possenti. São Paulo: Parábola Editorial, 2008a.

O ethos na análise do discurso de Dominique Maingueneau. In: AMOSSY, Ruth (Org.). Imagens de si no discurso: a construção do ethos. São Paulo: Contexto, 2008b. p.16-27.

Ethos, cenografia, incorporação. In: AMOSSY, Ruth (Org.). Imagens de si no discurso: a construção do ethos. São Paulo: Contexto, 2008c. p. 69-92.

. O discurso literário. Tradução de Adail Sobral. São Paulo: Contexto, 2009.

Doze conceitos em Análise do Discurso. Tradução de Adail Sobral. São Paulo: Parábola Editorial, 2010.

PCNs. Parâmetros curriculares nacionais: terceiro e quarto ciclos do ensino fundamental: língua portuguesa/Secretaria de Educação Fundamental. Brasília: MEC/SEF, 1998.

POSSENTI, Sírio. Contribuições de Dominique Maingueneau para a Análise do Discurso do Brasil. São Carlos: Pedro \& João Editores, 2008.

PRODANOV, Cleber C.; FREITAS, Ernani C. Metodologia do trabalho científico: métodos e técnicas da pesquisa e do trabalho acadêmico. Novo Hamburgo: Feevale, 2009.

SOUZA-E-SILVA, Cecília P.; ROCHA, Décio. Por que ler gênese dos discursos? Resenha de "Gênese dos discursos", de Dominique Maingueneau. ReVEL, v. 7, n. 13, 2009. Disponível em:<www.revel.inf.br $>$. Acesso em: 17 maio 2012.

ZILBERMAN, Regina. Estética da recepção e história da literatura. São Paulo: Ática, 1999. 